Bangladesh J. Bot. 40(2): 155-162, 2011 (December)

\title{
COMPARATIVE LEAF ANATOMY OF SOME ENDEMIC CROCUS L. TAXA FROM TURKEY
}

\author{
NeZaHAT KANDEMiR \\ Department of Biology, Education Faculty, Amasya University, Amasya-Turkey \\ Key words: Crocus, Endemic, Leaf anatomy, Relationships
}

\begin{abstract}
Relationships among 14 Crocus L. taxa such as, C. ancyrensis (Herbert) Maw, C. baytopiorum Mathew, C. biflorus Miller ssp. crewei (Hook.) Mathew, C. biflorus ssp. isauricus (Siehe ex Bowles) Mathew, C. biflorus ssp. nubigena (Herbert) Mathew, C. biflorus ssp. pseudonubigena Mathew, C. cancellatus Herbert ssp. cancellatus, C. cancellatus ssp. damascenus (Herb ert) Mathew, C. cancellatus ssp. lycius Mathew, C. cancellatus ssp. mazziaricus (Herbert) Mathew, C. cancellatus ssp. pamphylicus Mathew, C. pestalozzae Boiss., C. reticulatus Steven ex Adams ssp. hittiticus (T. Baytop \& Mathew) Mathew and C. sieheanus Barr ex Burtt collected from different two locations of Turkey have been investigated using 11 anatomic leaves characters. These taxa are endemic (except ssp. damascenus) and rare in Turkey. The anatomical variations in the cross sections of the leaf parts of the taxa were ascertained by statistical methods. It appears that the length and breadth measurements of palisade and spongy parenchyma cells, trachea diameter and cuticle thickness are important leaf anatomical characters that show variation in relation to altitudes.
\end{abstract}

\section{Introduction}

Genus Crocus (Iridaceae) comprises approximately 88 species distributed in the Mediterranean region. The taxa are distributed both in Turkey and in South Western Europe, South-Western parts of Asia and Western part of China (Alavi-Kia et al. 2008, Petersen et al. 2008, Kandemir 2009). Turkey has many endemic and rare Crocus taxa. Seventy two taxa are distributed in Turkey and 35 of them are endemic (Mathew 1984, 1988; 2000, Kerndorff and Pasche 2004, Özhatay et al. 2009). When the diversity of the taxa is taken into consideration, Turkey may be considered as the homeland of Crocus taxa. The investigated taxa are placed to Reticulati series (C. ancyrensis, C. cancellatus, C. reticulatus and C. sieheanus) and Biflori series (C. biflorus and C. pestalozzae) of Nudiscapus sectio and Verni series (C. baytopiorum) of Crocus sectio.

Crocus taxa have an important place among the geophyte plants. Because of this beatiful flowers, they are used as ornamental plants in the balconies, terraces and roof gardens (specially, C. baytopiorum, ssp. mazziaricus, ssp. lycius and ssp. damascenus). People in some regions of Anatolia make a local cheese called "herbed cheese" and "Crocus pilaf" from Crocus species (specially ssp. damascenus) (Baytop 1984). The extract of Crocus taxa has antitumor, antimutagenic and cytototic activities (Nair et al. 1991, Abdullaev 2003). Therefore, they are used for Behçet and gut diseases, treatment of joint pains and cancer research, recently.

The leaf anatomy of Crocus, leaf anatomy and phylogeny of Iridaceae family, the comparative morpho-anatomical, phylogenetic relationships and genetic diversity studies on the genus Crocus have been investigated by Rudall and Mathew (1990), Rudall and Goldblatt (1991), Pulido et al. (2004), Kandemir (2009, 2010), Petersen et al. (2008) and Alavi-Kia et al. (2008). Rudall and Mathew (1990) reported that the leaves of most Crocus species have a unique and distinctive shape in cross section and have a square and rectangular keel in the center and two

E-mail: <nezahatkndmr@gmail.com>. 
lateral arms. Moreover, some researchers found that the anatomic characters of leaves are important taxonomically (Rudall and Mathew 1990, Kandemir 2009, 2010).

Ekim et al. (2000) placed these taxa into endangered categories Lc (least concern, C. ancyrensis, ssp. isauricus, ssp. nubigena and ssp. pseudonubigena, ssp. cancellatus), nt (near threatened, ssp. lycius) and VU (vulnerable, ssp. crewei, ssp. pamphylicus, C. pestalozzae, ssp. hittiticus, C. sieheanus and C. baytopiorum).

The aim of this paper, is to determine the degree of relationship among 14 Crocus taxa and based on the leaf anatomic characters by statistical methods, and to determine the intra and interspecific variations.

\section{Materials and Methods}

The taxa in this study were collected from two different locations of Turkey in spring and autumn between 2008 and 2010 and sampling locations are given in Table 1. Taxonomic description of the taxa were made according to Mathew (1984). For anatomical studies, fresh plant

Table 1. The localities from where Crocus taxa were collected in Turkey."E" indicates endemic.

\begin{tabular}{|c|c|}
\hline Taxon & Localities \\
\hline C. ancyrensis (E) & $\begin{array}{l}\text { Amasya: Kırklar Mountain, open areas, } 710 \text { m., } 23 \text { March 2008, Kandemir, } 500 . \\
\text { Amasya: Merzifon, Bakırçay valley, open areas, } 1300 \text { m., } 2 \text { April 2008, Kandemir, } 501 .\end{array}$ \\
\hline C. baytopiorum (E) & $\begin{array}{l}\text { Denizli: Honaz Mountain, National Park stony areas, } 2450 \text { m., } 2 \text { April 2010, Çelik, } 502 . \\
\text { Denizli: Bozdağ, Tavas, Nikfer } 2050 \text { m., } 28 \text { April 2010, Çelik, } 503 .\end{array}$ \\
\hline C. biflorus ssp. crewei & $\begin{array}{l}\text { Denizli: Honaz Mountain, National Park stony areas, } 2520 \text { m., } 2 \text { April 2010, Çelik, } 504 . \\
\text { Denizli: Bozdağ, Tavas, Nikfer, } 2030 \text { m., } 28 \text { April 2010, Çelik, } 505 .\end{array}$ \\
\hline $\begin{array}{l}\text { C. biflorus ssp. } \\
\text { isauricus (E) }\end{array}$ & $\begin{array}{l}\text { Antalya: Termessos Park, Güllük Mountain, mezarlık district, stony areas, } 950 \text { m., } 28 \\
\text { February 2009, Kandemir, } 506 . \\
\text { Gaziantep: Yeşilce Village-Sof Mountain, Quercus forest, 1100-1200 m., } 18 \text { March 2009, } \\
\text { Kandemir, 507. }\end{array}$ \\
\hline $\begin{array}{l}\text { C. biflorus ssp. } \\
\text { nubigena }(\mathrm{E})\end{array}$ & $\begin{array}{l}\text { Balıkesir: Sındırgı, Kocabey village, open areas, } 700 \text { m., } 4 \text { February 2010, Kandemir, } 508 . \\
\text { Muğla: Göktepe, open areas, } 1850 \text { m., } 20 \text { March 2010, Kandemir, } 509 .\end{array}$ \\
\hline $\begin{array}{l}\text { C. biflorus ssp. } \\
\text { pseudonubigena }(\mathrm{E})\end{array}$ & $\begin{array}{l}\text { Maraş: Maraş district, shrub areas, } 800 \text { m., } 29 \text { October 2009, Kandemir, } 510 . \\
\text { Gaziantep: Yeşilce Village-Sof Mountain, Quercus forest, 1000-1100 m., } 4 \text { November } \\
\text { 2009, Kandemir, } 511 .\end{array}$ \\
\hline $\begin{array}{l}\text { C. cancellatus ssp. } \\
\text { cancellatus (E) }\end{array}$ & $\begin{array}{l}\text { Gaziantep: Gaziantep University Campus, shrub areas, } 600 \text { m., } 15 \text { October } 2009 \text {, } \\
\text { Kandemir, } 512 . \\
\text { Gaziantep: Sofalıcı Village, stony areas, } 1200-1300 \text { m., } 7 \text { November } 2009 \text {, Kandemir, } 513 .\end{array}$ \\
\hline $\begin{array}{l}\text { C. cancellatus ssp. } \\
\text { damascenus }\end{array}$ & $\begin{array}{l}\text { Şanlıurfa: Direkli Hills, Huzurevi around, rocky areas, } 700 \text { m., } 24 \text { October 2008, Kandemir, } \\
514 . \\
\text { Gaziantep: Nur Mountain, Gaziantep to Fevzipaşa, rocky areas, } 1650 \text { m., } 10 \text { November } \\
\text { 2008, Kandemir, } 515 .\end{array}$ \\
\hline $\begin{array}{l}\text { C. cancellatus ssp. } \\
\text { lycius (E) }\end{array}$ & $\begin{array}{l}\text { Muğla: Muğla to Fethiye, rocky slopes areas, } 340 \text { m., } 17 \text { October 2008, Kandemir, } 516 . \\
\text { Antalya: Kaş to Akçay, Sarnıç meadow areas, } 1400 \text { m., } 25 \text { October 2008, Kandemir, } 517 .\end{array}$ \\
\hline $\begin{array}{l}\text { C. cancellatus ssp. } \\
\text { mazziaricus }\end{array}$ & $\begin{array}{l}\text { Balıkesir: Savaştepe, Kozören village, open areas, } 500 \text { m., } 5 \text { December 2010, Kandemir, } \\
518 . \\
\text { Denizli: Honaz Mountain, stony areas, } 900 \text { m., } 10 \text { December } 2010 \text {, Çelik, } 519 \text {. }\end{array}$ \\
\hline
\end{tabular}




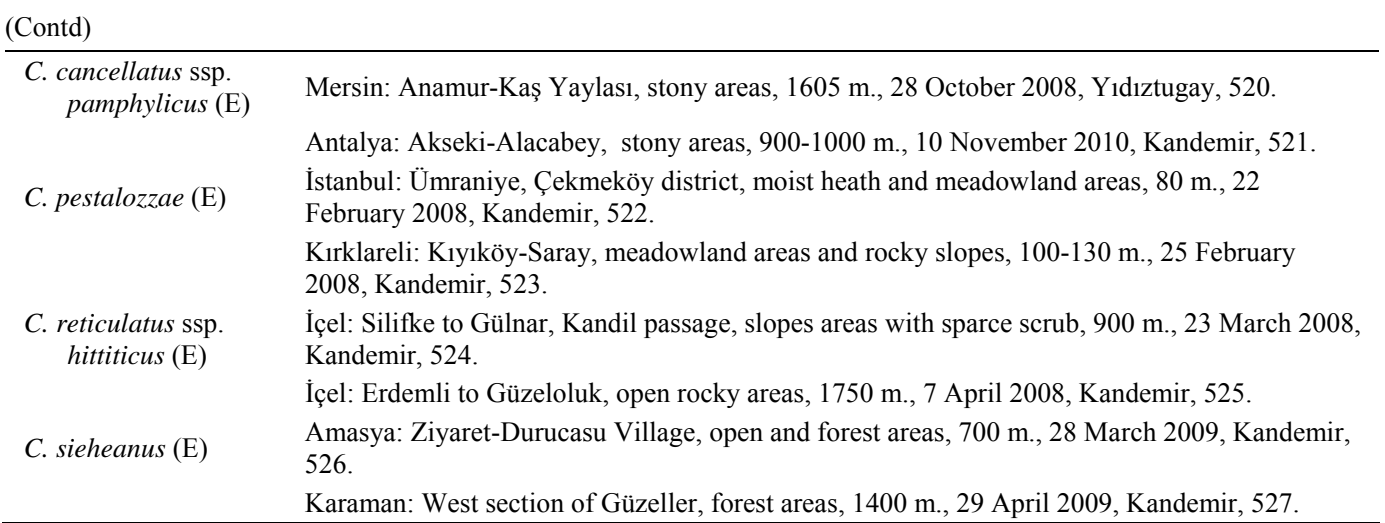

samples were preserved in $70 \%$ alcohol solution. Parafin method was used for preparing cross sections of the leaf parts (Algan 1981). The cross section of the plant samples collected from two different localities were taken by microtome and the anatomical measurements were made. The binocular microscope with drawing tube was used for drawings (samples). For the stasistical analysis, 11 characters of the leaves were used. The importance of difference between the leaf anatomic measurements of taxa at different altitudes and similarities were evaluated by using ttest. Mean and standard deviation values of the leaf anatomic measuments of taxa are given in Tables 2 and 3.

\section{Results and Discussion}

Generally, the leaves of Crocus taxa consisted of two lateral arms triangular (ssp. isauricus, ssp. nubigena, ssp. pseudonubigena, ssp. cancellatus, ssp. pamphylicus, C. pestalozzae and C. sieheanus) (Fig. 1d-g, k, 1 and n) or rectangular (C. ancyrensis, C. baytopiorum, ssp. crewei, ssp. damascenus, ssp. mazziaricus, ssp. lycius, and ssp. hittiticus) (Fig. 1a-c, h-j and m) keel in the median region. The margins of arms are usually recurved (C. baytopiorum, ssp. crewei, ssp. nubigena, ssp. damascenus, ssp. pseudonubigena, ssp. cancellatus, ssp. pamphylicus, C. pestalozzae and C. sieheanus) towards the keel (Kandemir 2009). The keel filled with large parenchyma cells, called lacuna. The abaxial side of arms have 2-4 protrusions (ssp. pseudonubigena, ssp. isauricus and ssp. nubigena) and 4-6 protrusions (ssp. crewei). Micropapillae were conspicuous on the cuticle of arms (C. ancyrensis, C. baytopiorum, ssp. crewei, ssp. isauricus, ssp. nubigena, ssp. lycius, ssp. mazziaricus, and ssp. hittiticus, C. pestalozzae and C. sieheanus). But, micropapillae were evidently conspicuous on the cuticle of arms of ssp. cancellatus, ssp. pamphylicus and ssp. damascenus. All of the taxa stoma cells were on the groove parts of keel and anomocytic shaped. They were in sunken position between epidermis cells with micropapillae (C. ancyrensis, ssp. isauricus, ssp. nubigena, ssp. pseudonubigena, ssp. cancellatus, C. pestalozzae and C. sieheanus). While epidermis cells on groove part of leaves of C. baytopiorum, ssp. nubigena, ssp. pseudonubigena, ssp. damascenus, ssp. pamphylicus and C. pestalozzae had straight sinuous walls, epidermis cells on groove parts of leaves of ssp. crewei, ssp. isauricus, ssp. cancellatus and ssp. hittiticus had sinuous. Mesophyll consisted of palisade and spongy parenchyma. The palisade parenchyma was 2 layered $(C$. ancyrensis, ssp. crewei, ssp. isauricus, ssp. nubigena, ssp. lycius, ssp. mazziaricus, C. pestalozzae and C. sieheanus), 1-2 layered (C. baytopiorum, ssp. pseudonubigena, spp. pamphylicus and ssp. 


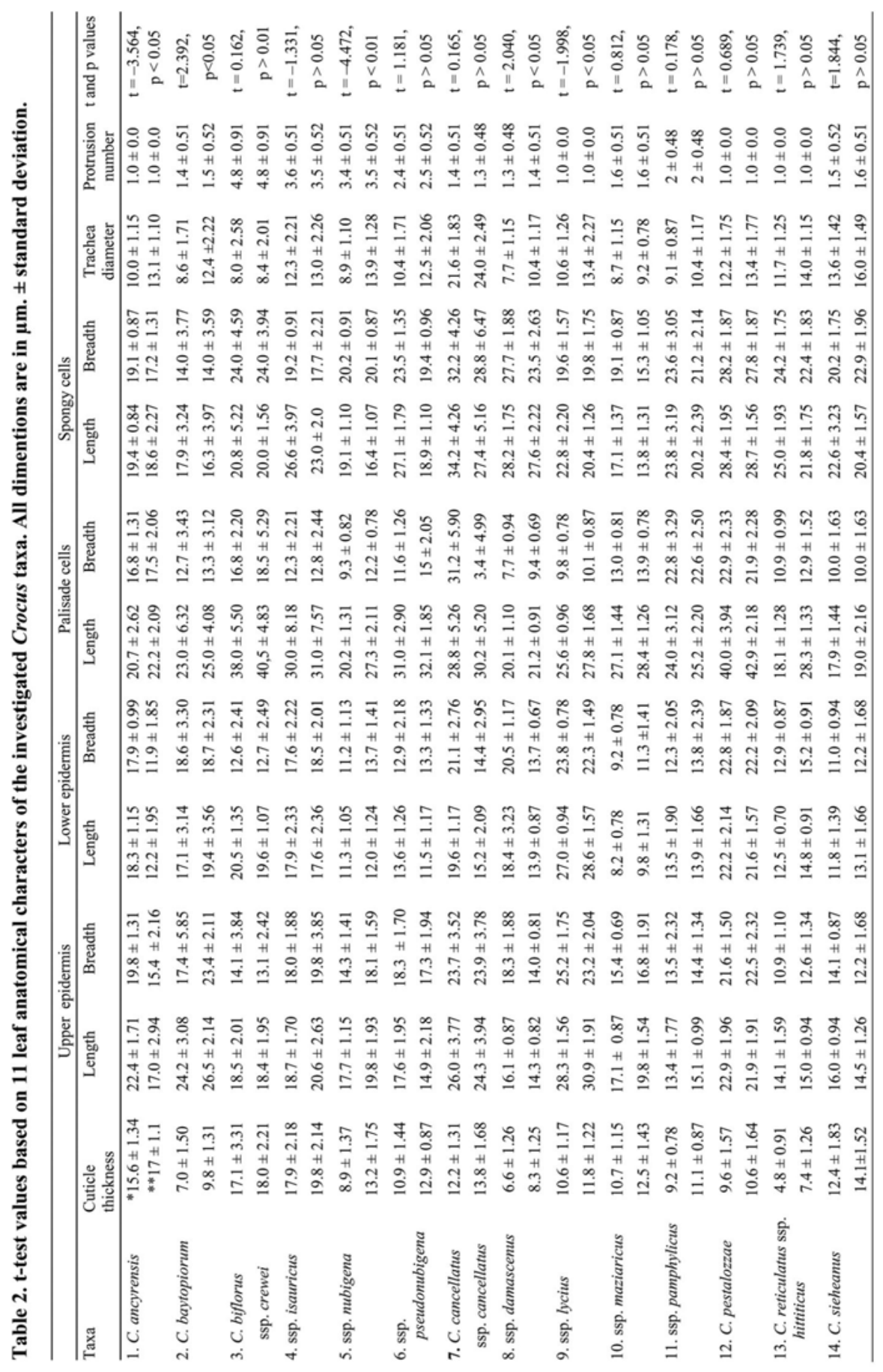


hittiticus) and 3-4 layered (ssp. damascenus). The spongy parenchyma was 2-3 layered (ssp. crewei, ssp. pseudonubigena, ssp. hittiticus and C. sieheanus), 3 layered (C. baytopiorum and ssp. isauricus) and 3-5 layered (C. ancyrensis, ssp. nubigena, ssp. damascenus, ssp. lycius, ssp. mazziaricus, ssp. pamphylicus and C. pestalozzae). In ssp. cancellatus, mesophyll composed of only 3-5 layered and oval shaped parenchyma cells. There were four large vascular bundles and different number of small vascular bundles in leaves. Two of large bundles were at the corners of the keel and the other two are at the end of arms. The small bundles were between the arms and the keel. The bundle sheath consisted of sclerenchyma cells at the phloem pole of the large bundles. There were sclerenchyma cells either at the phloem poles (C. ancyrensis, C. baytopiorum, ssp. crewei, ssp. nubigena, ssp. cancellatus, ssp. damascenus, ssp. lycius, ssp. mazziaricus, ssp. pamphylicus and C. sieheanus) or the phloem and xylem poles (ssp. isauricus, ssp. pseudonubigena, C. pestalozzae and ssp. hittiticus) of large and small bundles. All of these anatomic characters have taxanomic significance.
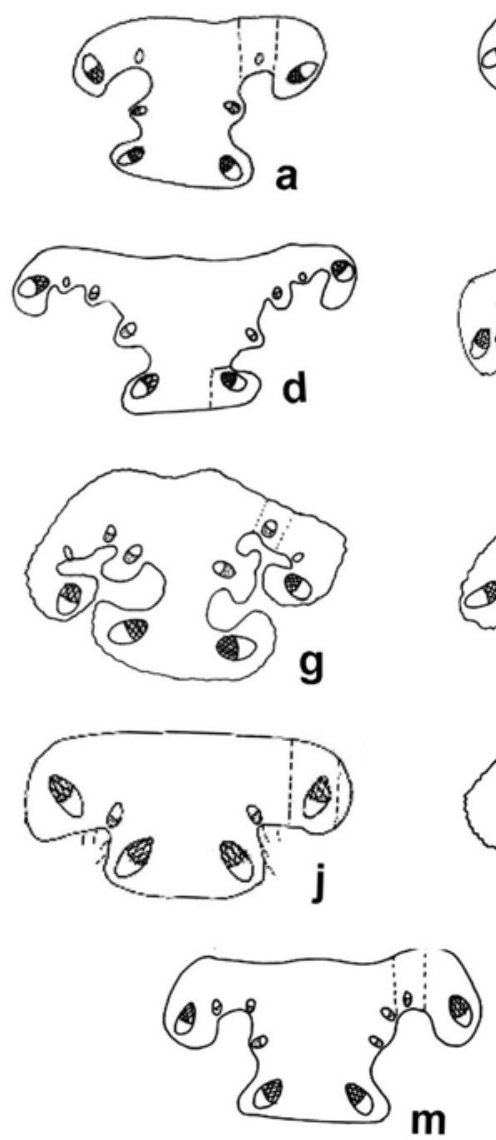
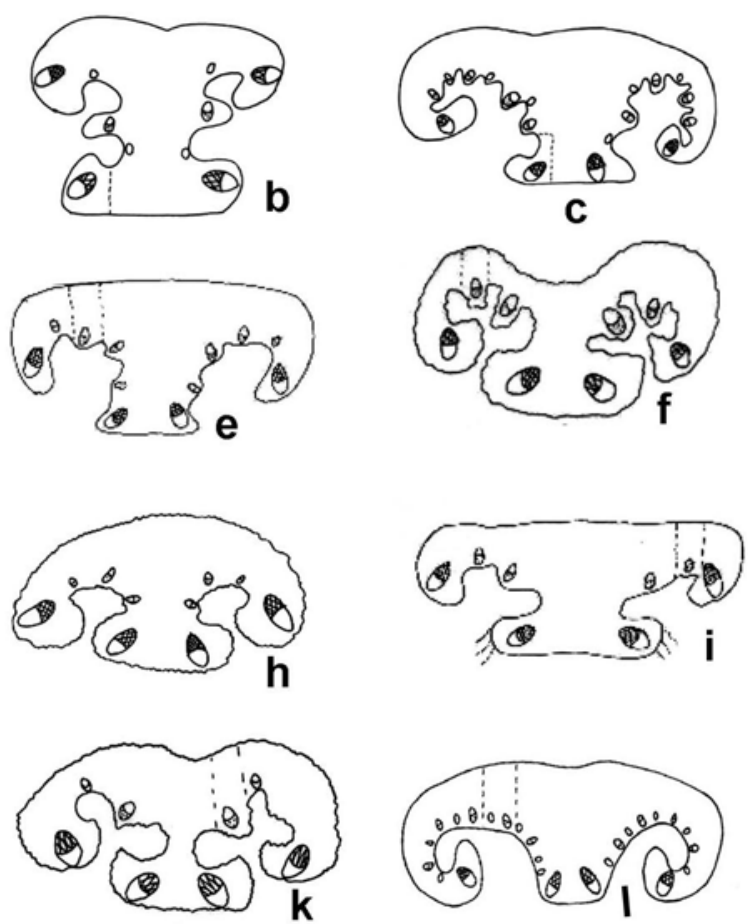

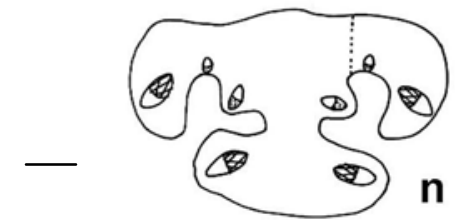

Fig. 1. The general drawing of the Crocus leaves: a. C. ancyrensis, b. C. baytopiorum, c. C. biflorus ssp. crewei, d. C. biflorus ssp. isauricus, e. C. biflorus ssp. nubigena, f. C. biflorus ssp. pseudonubigena, g. C. cancellatus ssp. cancellatus, h. C. cancellatus ssp. damascenus, i. C. cancellatus ssp. mazziaricus, j. C. cancellatus ssp. lycius, k. C. cancellatus ssp. pamphylicus, 1. C. pestalozzae, m. C. reticulatus ssp. hittiticus, n. C. sieheanus $(\mathrm{Bar}=400 \mu \mathrm{m})$. 
They show considerable variation in morphologic characters, since C. biflorus and $C$. cancellatus are complex and wide geographically distributed taxa. Thus, there are problems in taxonomic of these two taxa. Although there is high homoplosy between both morphologic and anatomic characters, leaf anatomy provides some significant data for Iridaceae, especially at the tribus levels (Rudall 1994). Moreover, anatomical and palynological data can be used to infer phylogenetic relations among the Crocus taxa (Almida et al. 2009). While the ssp. maziaricus, ssp. lycius and ssp. damascenus, ssp. cancellatus as morphologic are closer to each other, the ssp. pamphyllicus is a different subspecies. According to the general leaf anatomy, it is seen that ssp. pamphylicus and ssp. cancellatus are similar to each other and ssp. maziaricus and ssp. lycius are also similar (Kandemir et al. 2011). Statistically, we have found that there are differences and similarities among subspecies of $C$. cancellatus respect to the leaf anatomic characters. But, ssp. damascenus are significantly different from other subspecies of $C$. cancellatus relating to the general leaf anatomy. It is concluded that there are similarities in anatomic characters of ssp. damascenus and C. pallasi ssp. turcicus by Akan and Eker (2004). However, the vascular bundles of ssp. damascenus are more abundant and regular. In this study, it is also seen that this subspecies is similar to C. pallasi ssp. turcicus. The two subspecies are relatively isolated taxonomically. It is considered that these the two subspecies are closely related.

On the other hand, although there are anatomic and morphologic differences between the subspecies of C. biflorus, it is seen that ssp. isauricus, ssp. crewei and ssp. nubigena (except ssp. pseudonubigena) are closer subspecies to each other relating to leaf anatomic characters. According to the statistical results, there are important correlations among ssp. crewei, ssp. isauricus and ssp. nubigena which are subspecies of C. biflorus at the level of $p>0.05$ (Table 3). This similar phenomenon has been found in polen morphology of subspecies of C. biflorus (except ssp. nubigena) by Işık and Dönmez (2006). Despite the ssp. pseudonubigena is a subspecies of $C$. biflorus and ssp. cancellatus is a subspecies of C. cancellatus, they are close subspecies to each other according to their leaf anatomic structure. These similarities between two subspecies are

Table 3. Correlation based on t- test between investigated 14 Crocus taxa.

\begin{tabular}{|c|c|c|c|c|c|c|c|c|c|}
\hline Taxon & $\begin{array}{c}\text { Mean } \\
\text { difference }\end{array}$ & t value & $\mathrm{p}$ values & $\begin{array}{l}\text { Signi- } \\
\text { ficance }\end{array}$ & Taxon & $\begin{array}{c}\text { Mean } \\
\text { difference }\end{array}$ & t value & $\mathrm{p}$ value & $\begin{array}{l}\text { Signi- } \\
\text { ficance }\end{array}$ \\
\hline $3-4$ & 0.30 & 0.209 & $\begin{array}{c}0.839 \\
p>0.05\end{array}$ & $\mathrm{NS}$ & $6-7$ & -5.17 & -2.75 & $\begin{array}{c}0.020 \\
p>0.01\end{array}$ & $\mathrm{NS}$ \\
\hline $3-5$ & 0.50 & 0.953 & $\begin{array}{c}0.345 \\
p>0.05\end{array}$ & NS & $6-8$ & 0.49 & 0.31 & $\begin{array}{c}0.763 \\
p>0.05\end{array}$ & NS \\
\hline $4-5$ & 1.70 & 0.643 & $\begin{array}{c}0.655 \\
p>0.01\end{array}$ & NS & $7-8$ & 5.66 & 2.28 & $\begin{array}{c}0.045 \\
\mathrm{p}<0.05\end{array}$ & $*$ \\
\hline $3-12$ & -3.17 & -2.06 & $\begin{array}{c}0.065 \\
p>0.05\end{array}$ & NS & $8-9$ & 4.97 & 2.23 & $\begin{array}{c}0.040 \\
\mathrm{p}<0.05\end{array}$ & $*$ \\
\hline $3-6$ & 1.29 & 3.960 & $\begin{array}{c}0.037 \\
p<0.05\end{array}$ & $*$ & $8-10$ & 5.47 & 3.68 & $\begin{array}{c}0.039 \\
\mathrm{p}<0.05\end{array}$ & $*$ \\
\hline $4-6$ & 1.07 & 3.925 & $\begin{array}{c}0.039 \\
p<0.05\end{array}$ & $*$ & $8-11$ & 6.64 & 4.89 & $\begin{array}{c}0.001 \\
\mathrm{p}<0.01\end{array}$ & $* *$ \\
\hline $5-6$ & 1.18 & -3.144 & $\begin{array}{c}0.010 \\
p<0.05\end{array}$ & $*$ & $7-11$ & 0.98 & 0.53 & $\begin{array}{c}0.607 \\
p>0.05\end{array}$ & NS \\
\hline $1-13$ & 1.27 & 0.66 & $\begin{array}{c}0.51 \\
\mathrm{p}>0.05\end{array}$ & NS & $9-10$ & 0.94 & 0.23 & $\begin{array}{c}0.849 \\
p>0.05\end{array}$ & NS \\
\hline $1-14$ & 1.03 & 0.63 & $\begin{array}{c}0.54 \\
p>0.05\end{array}$ & NS & $13-14$ & -0.23 & 0.23 & $\begin{array}{c}0.823 \\
p>0.05\end{array}$ & NS \\
\hline
\end{tabular}

NS, non significant; * significant at the level of 0.05 ; ** significant at the level of 0.01

supported by statistical results (Table 3, p > 0.05). Also, the soil analysis results of ssp. pseudonubigena showed a different subspecies of C. biflorus (Kandemir et al. 2011). So, the 
taxanomic status of ssp. pseudonubigena and ssp. damascenus should be designed relating to their leaf anatomic and ecologic characters.

According to statistical analysis, it is seen that the leaf character measurements of ssp. crewei, ssp. isauricus, ssp. pseudonubigena, ssp. cancellatus, ssp. mazziaricus, ssp. pamphylicus, C. pestalozzae, ssp. hittiticus and C. sieheanus do not have any significant changes at different altitudes (Table 2, $\mathrm{p}>0.05$ ). However, there have seen more or less variations about the leaf anatomic measurements of $C$. ancyrensis, C. baytopiorum, ssp. nubigena, ssp. damescanus and ssp. lycius relating to the altitude (Table $2, \mathrm{p}<0.05$ ). As shown in table 3 , there are statistically important differences among 3-6, 4-6, 5-6, 7-8, 8-9, 8-10 and 8-11 taxa at levels of 0.05 and 0.01 . The reason of these differences may be caused the distribution of these taxa at different ecological conditions. On the other hand, there are no statistically important differences among 3-4, 3-5, 4-5, 3-12, 1-13, 1-14, 6-7, 6-8, 7-11, 9-10 and 13-14 taxa (Table 3, p > 0.05). Also, ssp. crewei and $C$. pestalozzae, C. ancyrensis and C. sieheanus, C. ancyrensis and ssp. hittiticus, C. sieheanus and ssp. hittiticus are closer to each other based on leaf anatomic characters (Table 3, p > 0.05). The similarities between these taxa may be originated from their distribution at similar ecologic conditions. When the altitude increases, in the leaf anatomic measurements (specially, palisade parenchyma beadth and length, cuticle thickness and trachea diameter) of taxa are seen increased. But, in measurements of breadth and length of spongy parenchyma are seen decreased (Table 2).

As a general, there have found to have differences among the taxa in leaf anatomic characters such as the layer number and structure of mesophyll, shape of the epidermis cells, whether they have sinuous on epiderma, shape and base structure of keel, whether they have sclerenchyma in vascular bundles, number and the status of vascular bundles and protrusions number in arms. It appeared that the leaf characters mentioned may be used as important taxonomic characters of Crocus taxa. It is determined that palisade and spongy parenchyma length-breadth, trachea diameter and cuticle thickness are the best characters which represent the anatomic variations between these taxa relating to altitude (Table 2). There may be a xeromorphic adaptation, because, some taxa have sunkened stomata and triangular keel structure. In other anatomic characters considerable variations were not found.

\section{References}

Abdullaev FL 2003. Crocus sativus against cancer. Archives Med. Res. 34: 354.

Akan H and I Eker 2004. Some Morphological and Anatomical Investigations on Autumn Species of Crocus L. Occurring in Şanliurfa. Turk. J. Bot. 28: 185-191.

Alavi-Kia SS, SA Mohammadi, S Aharizad, M Moghaddam 2008. Analysis of genetic diversity and phylogenetic relationships in Crocus genus of Iran using inter-retrotransposon amplified polymorphism. Biotechnol. Eq. 22: 795-800.

Algan G 1981. The microtechnic for plant tissues. Firat Univ. Press, Elazığ. 93 pp.

Almeida VR, AF Costa, A Mantovani, A Mantovani, V Gonçalves-Esteves, RCO Aruuda and RC Forzza 2009. Morphological phylogenetics of Quesnelia (Bromeliaceae). Sys. Bot. 34: 660-672.

Baytop T 1984. Therapy with medicinal plant in Turkey, past and present. Nobel Tıp Press, İstanbul. 321 pp.

Coşkun F, S Selvi and F Satıl 2010. Phylogenetic relationships of some Turkish Crocus (Iridaceae) taxa based on morphological and anatomical characters. Turk. J. Bot. 34: 171-178.

Ekim T, M Koyuncu, M Vural, H Duman, Z Aytaç and N Adıgüzel 2000. Red Data of Turkish Plants. The council of Protecting the Turkısh Nature Press, Ankara. 95-96 pp.

Işık S and EO Dönmez 2006. Pollen morphology of some Turkısh Crocus L. (Iridaceae) species. Acta Biol. Cracov. 48: 85-91.

Kandemir N 2009. A morphology, anatomy and ecology of critically endangered endemic Crocus pestalozzae Boiss. (Iridaceae) in North-West Turkey. Bangladesh J. Bot. 38(2): 127-132. 
Kandemir N 2010. A morphological and anatomical investigation about two rare and endemic Crocus taxa (Iridaceae) from Southern Anatolia. EurAsia J. BioSci. 4: 54-62.

Kandemir N, A Çelik and F Yayla 2011. Comparative anatomic and ecologic investigations on some endemic Crocus taxa (Iridaceae) in Turkey. Pak. J. Bot. (in press).

Kerndorff $\mathrm{H}$ and $\mathrm{E}$ Pasche 2004. Two new taxa of the Crocus biflorus aggregate (Liliiflorae, Iridaceae) from Turkey. Linzer Biologische Beitrage 36: 5-10.

Mathew BF 1984. Crocus. In: Flora of Turkey and the East Aegean Islands, PH Davis (Ed), pp. 423-438. Edinburg Univ. Press, London.

Mathew BF 1988. Crocus L. In: Flora of Turkey and the East Aegean Islands, PH Davis, RR Mill, K Tan (Eds), pp. 228. Edinburg Univ. Press, London.

Mathew BF 2000. Crocus L. In: Flora of Turkey and the East Aegean Islands, A. Güner, N Özhatay, T Ekim, KHC Başer (Eds), pp. 271-274. Edinburg Univ. Press, London.

Nair SC, B Pannikar and KR Panikkar 1991. Antitumour activity of saffron (C. sativus). Cancer Letters 57(2): 109-114.

Özhatay N, Ş Kültür and S Aslan 2009. Check-list of additional taxa to the supplement Flora of Flora of Turkey IV. Turk. J. Bot. 33: 191-226.

Petersen G, O Seberg, S Thorsoe, T Jorgensen and B Mathew 2008. A phylogeny of the genus Crocus (Iridaceae) based on sequence data from five plastid regions. Taxon. 57(2): 487-499.

Pulido L, S Gattuso and M Gattuso 2004. Comparative morphoanatomical study of three species pertaining to the Crocus genus: C. nevadensis, C. nudiflorus and C. sativus differentiating characteristics. Acta Hort. 650: 59-65.

Rudall P and B Mathew 1990. Leaf anatomy in Crocus (Iridaceae). Kew Bull. 45(3): 535-544.

Rudall P and P Goldblatt 1991. Leaf anatomy and phylogeny of Ixioideae (Iridaceae). Bot. J. Lin. Soc. 106 (4): 329-345.

Rudall P 1994. Anatomy and systematics of Iridaceae. Bot. J. Lin. Soc. 114: 1-21.

Satıl F and S Selvi 2007. An anatomical and ecological study of some Crocus L. taxa (Iridaceae) from the west part of Turkey. Acta Bot. Croat. 66(1): 25-33.

(Manuscript received on 20 August, 2011; revised on 5 October, 2011) 